\title{
CURCUMIN IN ORAL MUCOSAL LESIONS: AN UPDATE
}

\author{
ARPITA RAI ${ }^{1 *}$, ANSUL KUMAR ${ }^{2}$, SHAMIMUL HASAN ${ }^{1}$, SHAZINA SAEED ${ }^{3}$
}

${ }^{1}$ Department of Oral Medicine and Radiology, Faculty of Dentistry, Jamia Millia Islamia, New Delhi, India. ${ }^{2}$ Department of CTVS, Rajendra Institute of Medical Sciences, Ranchi, Jharkhand, India. ${ }^{3}$ Amity Institute of Public Health, Amity University, Noida, Uttar Pradesh, India. Email: arai@jmi.ac.in

Received: 08 September 2017, Revised and Accepted: 10 October 2018

ABSTRACT

The phytopharmaceutical curcumin - the Indian golden spice has been widely researched for its pharmaceutical properties. It exhibits a big promise as a therapeutic agent due to its properties such as antioxidant, analgesic, anti-inflammatory, antiseptic activity, anticarcinogenic activity, chemopreventive, chemotherapeutic activity, antitumor, antiviral, antibacterial, and antifungal and is currently in human trials for a variety of conditions. The applications of curcumin in dentistry include its use as pit and fissure sealant, dental plaque detection system, subgingival irrigant, and intracanal medicament. The aim of the present paper is to review the current literature for the use of curcumin in oral mucosal lesions. A thorough review of the existing literature encompassing PubMed, Ovid, Embase, and Google scholar was made using the keywords curcumin, turmeric, oral, mucosal, oral submucous fibrosis (OSMF), oral lichen planus (OLP), aphthous, recurrent aphthous stomatitis (RAS), leukoplakia, mucositis, reverse smoking, tobacco-associated lesions, and premalignant. No filters in relation to language or publication year were used and only in vivo studies on humans were selected. Reference lists of retrieved journal articles were searched for publications missed during the primary search. Finally, the Google search engine was used to do a comprehensive search of the World Wide Web to ensure completeness of the search. The review of the literature revealed evidence of the use of curcumin in tobacco-associated conditions of the oral cavity-OSMF, oral leukoplakia, oral lesions associated with reverse smoking and ulcerative conditions of the oral cavity- OLP, RAS, and oral mucositis has been studied. Curcumin provides the basis for a simple, safe, acceptable, and cost-effective intervention for oral mucosal disorders.

Keywords: Curcumin, Oral leukoplakia reverse smoking, Oral lichen planus, Oral mucosal lesions, Oral mucositis, Oral potentially malignant disorders, Oral submucous fibrosis, Oral ulcers, Premalignant, Recurrent aphthous stomatitis, Recurrent aphthous, Tobacco-associated lesions, Treatmentinduced oral mucositis, Turmeric.

(C) 2019 The Authors. Published by Innovare Academic Sciences Pvt Ltd. This is an open access article under the CC BY license (http://creativecommons. org/licenses/by/4. 0/) DOI: http://dx.doi.org/10.22159/ajpcr.2019.v12i2.22458

\section{INTRODUCTION}

In this era of herbal renaissance, the use of herbal agents in medicine and dentistry is gaining importance worldwide. One such nutraceutical is turmeric which has come all the way from the kitchen to clinic. Turmeric is a perennial herb of Zingiberaceae family [1]. Its botanical name is Curcuma longa. The rhizomes of this plant are dried and powdered to yield the spice turmeric. The name turmeric originates from the Persian word "kirkum," meaning saffron, given due to its effervescent yellow-orange color [2].

Turmeric has been used in several ancient medicinal systems such as Ayurveda, Sidhha, Unani, and Chinese systems of medicine. Its documented use dates back to 6000 years [3]. The medicinal properties of turmeric were later discovered. Turmeric is indigenous to Southeast Asia. Indian contribution to the total world production of turmeric is $93.3 \%$ [3]. The estimated size of the Indian turmeric industry is 2500-3000 crores [4]

Several components, $>100$, have been isolated from turmeric. The major constituent of the root is a volatile oil which is composed of turmerone, and coloring agents called curcuminoids [5]. Curcuminoids include curcumin, demethoxycurcumin, 5'-methoxycurcumin, and dihydrocurcumin, which are natural antioxidants [6]. Curcumin, the principal curcuminoid, comprises approximately $2-5 \%$ of turmeric [7]. It owes its importance by providing the yellow color to turmeric and also accounts for most of its pharmacological effects. Curcumin possesses numerous pharmacological properties, including antioxidant, anti-inflammatory, antimicrobial properties, chemopreventive, and chemotherapeutic activity [8]. Recently, apoptosis induction effect of curcumin and its analogs on cancer cell lines have been shown [9]. A recent review has highlighted the role of curcumin as a potent anticarcinogenic polyphenol [10].
Several papers have reviewed the role of turmeric or curcumin in dentistry. The applications of curcumin in dentistry include its use as pit and fissure sealant, dental plaque detection system, subgingival irrigant, and intracanal medicament [11]. The aim of the present paper is to review the current literature for the use of curcumin in oral mucosal lesions. The antioxidant, anticarcinogenic, and antiinflammatory properties of curcumin make it appropriate to explore the role of curcumin in oral mucosal disorders. A thorough review of the existing literature encompassing PubMed, Ovid, Embase, and Google scholar was made using the keywords curcumin, turmeric, oral, mucosal, oral submucous fibrosis (OSMF), oral lichen planus (OLP), aphthous, recurrent aphthous stomatitis (RAS), leukoplakia, mucositis, reverse smoking, tobacco-associated lesions, and premalignant. No filters in relation to language or publication year were used and only in vivo studies on humans were selected. Reference lists of retrieved journal articles were searched for publications missed during the primary search. Finally, the Google search engine was used to do a comprehensive search of the World Wide Web to ensure completeness of the search. The review of the literature revealed evidence of the use of curcumin in oral mucosal lesions such as OSMF, oral leukoplakia, oral lesion associated with reverse smoking, RAS, OLP, and oral mucositis. This first half of this review will focus on the use of curcumin in tobacco-associated lesions such as OSMF, oral leukoplakia, and lesion associated with reverse smoking. Reddy et al. have also highlighted the role of curcumin as an anti-cancer spice in their recent review [12].

\section{Curcumin in OSMF}

Pindborg defined OSMF as "insidious chronic disease affecting any part of the oral cavity and sometimes the pharynx, occasionally preceded by vesicle formation, always associated with juxtaepithelial inflammatory reaction followed by a fibroelastic change of lamina propria with 
epithelial atrophy leading to stiffness of the oral mucosa, trismus and inability to eat." [13]. It is a potentially malignant disorder mainly caused due to areca nut chewing characterized by restricted mouth opening, burning sensation on having hot and spicy food, and stiffness and blanching of the oral mucosa. The malignant transformation rate of OSMF has been reported to be around $27 \%$ over several years [14].

Curcumin exhibits several properties such as anti-inflammatory, antioxidant and proapoptotic activities, which account for its chemopreventive action and is, therefore, desirable for OSMF. Curcumin is a dual inhibitor of arachidonic acid metabolism and, therefore, inhibits the products of inflammation such as prostaglandins and leukotrienes [15]. Curcumin also has a role in the suppression of tumor necrosis factor (TNF)-induced nuclear factor- $\kappa \mathrm{B}$ (NF- $\kappa \mathrm{B})$ activation and NF-KB-dependent reporter gene expression [16]. Downregulation of several products involved in cellular proliferation (cyclooxygenase 2, cyclin D1, and c-myc), anti-apoptosis (IAP1, IAP2, XIAP, Bcl-2, Bcl-xL, Bfl-1/A1, TRAF1, and cellular cFLIP), and metastasis (vascular endothelial growth factor [VEGF], matrix metallopeptidase 9 [MMP-9], and intercellular adhesion molecule 1) by curcumin has been previously reported [17]. Rao et al. have demonstrated a very interesting effect of curcumin, namely the scavenging effect on superoxide radicals, hydroxyl radicals, and lipid peroxidation, considered a major etiopathogenetic factor of OSMF [18]. Recently, Zhang et al. demonstrated anti-fibrotic activity of curcumin in TGF- $\beta 1$-induced myofibroblasts from human oral mucosa, suggesting its utility in OSMF patients [19]. It has also been previously demonstrated that curcumin possesses fibrinolytic action in liver and lung fibrosis and is regarded as a fibrinolytic agent in Chinese medicine [20]. Li et al. have attributed the fibrinolytic action of curcumin to its three properties, namely inhibition of lipid peroxidation, checking cellular proliferation, and inhibition of collagen synthesis [21]. Curcumin also suppresses bleomycin-induced pulmonary fibrosis in rats [22].

The review of the literature reveals eight research papers which have been published assessing the efficacy of curcumin in OSMF patients (Table 1). Of these four are randomized control trials (RCTs), three are observational studies, and one is a pre-post study design. The most recently published literature is an RCT by Pipalia et al. [23]. This study evaluated the effectiveness of turmeric with black pepper and Nigella sativa in OSMF patients. Tumeric with black pepper and $N$. sativa improved mouth opening, burning sensation, and superoxide dismutase levels in OSMF patients. The rationale behind the use of black pepper was it prevents the metabolism of turmeric and therefore increases the bioavailability of turmeric. N. sativa due to its antioxidant, anti-inflammatory, anticarcinogenic, immunomodulatory, and antifibrotic properties was used. Furthermore, it has been tried in human studies for type II diabetes mellitus for glycemic control.

Hazarey et al. evaluated the efficacy of curcumin over standard medicinal management modality for OSMF [24]. The curcumin group was given Longvida lozenges (400 mg lozenges) with a total daily dose of $2 \mathrm{~g}$ and was compared to topical clobetasol propionate $0.05 \%$ to be applied 3 times daily for 3 months. The mean decrease in the Visual analogue scale score and increase in mouth opening was statistically significant in the curcumin group as compared to the control group. The authors proposed that curcumin being antioxidant and anti-inflammatory may enhance the neoangiogenic and antifibrotic potential of the OSMF patients.

The observational study by Srivastava et al. investigated the clinical efficacy of $1 \mathrm{~g}$ tulsi and $1 \mathrm{~g}$ turmeric mixed in glycerine base for the treatment of OSMF patients and found statistically significant improvement in both burning sensation and mouth opening in the study population [25]. They have hypothesized that ursolic acid (UA), a pentacyclic triterpene acid from Ocimum sanctum (Tulsi) has been reported to suppress NF-KB activation-induced by various carcinogens. In addition, UA prevents proliferation and induces apoptosis and cell arrest in the G1-G0 phase of the cell cycle [15]. Synergistic action of these two herbs resulted in potent anti-OSMF treatment characterized by an early, sustained and significant fall in burning sensation and improvement in mouth opening for severe cases reflecting its higher efficacy.

Table 1: Review of literature showing eight research papers assessing the efficacy of curcumin in OSMF patients

\begin{tabular}{lllll}
\hline S. No. & Author(s) & $\begin{array}{l}\text { Type of } \\
\text { evidence }\end{array}$ & n & Interventions \\
\hline 1. & Pipalia et al. & RCT & 23 & $\begin{array}{l}\text { Group A received turmeric } \\
\end{array}$ \\
& & & $(400 \mathrm{mg})$ with black pepper \\
& & & $(100 \mathrm{mg}), 2$ capsules TID for \\
& & & 3 months. Group B received \\
& & & Nigella sativa, two capsules of \\
& & & & \\
& & &
\end{tabular}

2. Hazarey et al. RCT

30 Test group patients were treated with Longvida (curcumin) lozenges and control group with tenovate ointment (clobetasol propionate $(0.05 \%)$

$\begin{array}{lll}\begin{array}{l}\text { Srivastava et al. Observational } \\ \text { study }\end{array} & 41 & \begin{array}{l}1 \mathrm{~g} \text { tulsi and } 1 \mathrm{~g} \text { turmeric } \\ \text { mixed } \\ \text { in glycerine base applied } \\ \end{array} \\ & 3-4 \text { times a day for } 3 \text { mont }\end{array}$

Outcomes Results

The mouth opening and burning sensation were the primary treatment outcome endpoints. Cheek flexibility

was also measured. Patients' serum SOD levels were assessed before and after treatment and also compared with healthy controls IID on maximum mouth opening, VAS for normal food, and VAS for spicy food

Burning sensation and mouth opening
After the treatment Groups A and B showed $3.85 \pm 0.22 \mathrm{~mm}$ and $3.6 \pm 0.07 \mathrm{~mm}$ improvement in mouth opening, respectively; $87.90 \%$ and $78.91 \%$ reduction in burning sensation, respectively; and $+0.62 \mathrm{U} / \mathrm{ml}$ and $+0.74 \mathrm{U} / \mathrm{ml}$ improvement in serum SOD levels, respectively The test group showed 5.93 ( \pm 2.37$) \mathrm{mm}$ increase in mouth opening compared to 2.66 $( \pm 1.76) \mathrm{mm}$ of the control group. In relation to VAS scale with spicy and normal food, the average reduction was 64 (42-73) and $77(70.5-82)$ as compared to 34 (14.5-64.5) and 64 (46-75.5), respectively in control group

Mean burning sensation was $6.07 \pm 1.75$ before the treatment and $2.22 \pm 1.41$ after the treatment $(\mathrm{t}=15.52$; $\mathrm{p}<0.001)$. Mean mouth opening was $24.46 \pm 4.0 \mathrm{~mm}$ before the treatment and $27.85 \pm 3.39 \mathrm{~mm}$ after the treatment $(\mathrm{t}=9.06$; $\mathrm{p}<0.001$ ) 
Table 1: (Continued)

\begin{tabular}{|c|c|c|c|c|c|c|}
\hline S. No. & Author(s) & $\begin{array}{l}\text { Type of } \\
\text { evidence }\end{array}$ & $\mathbf{n}$ & Interventions & Outcomes & Results \\
\hline 4. & Yadav et al. & RCT & 40 & $\begin{array}{l}\text { First group - weekly } \\
\text { intralesional injection of } 4 \mathrm{mg} \\
\text { dexamethasone and } \\
1500 \text { I.U hyaluronidase. } \\
\text { Second group - oral } \\
\text { administration of two tablets } \\
\text { (turmix - tablet containing } \\
\text { curcumin } 300 \text { mg and piperine } \\
5 \text { mg) per day for } 3 \text { months } \\
\text { each }\end{array}$ & $\begin{array}{l}\text { Improvement of burning } \\
\text { sensation, } \\
\text { IID and TP }\end{array}$ & $\begin{array}{l}\text { Improvement in burning } \\
\text { sensation was from } 22.4 \text { (8.7) to } \\
15.6(11.2) \text { in Group } 1 \text { compared } \\
\text { to } 63.5(24.7) \text { to } 0 \text { in curcumin } \\
\text { group. The mean increase in IID } \\
\text { was } 3.13 \text { and } 1.25 \mathrm{~mm} \text {. Mean } \\
\text { increase in TP was } 2.56 \mathrm{~mm} \\
\text { and } 0.38 \mathrm{~mm} \text { in Groups } 1 \text { and } 2 \text {, } \\
\text { respectively }\end{array}$ \\
\hline 5. & Agarwal et al. & $\begin{array}{l}\text { Observational } \\
\text { study }\end{array}$ & 30 & $\begin{array}{l}\text { Turmix (tablet containing } \\
\text { curcumin } 300 \mathrm{mg} \text { and piperine } \\
5 \mathrm{mg} \text { ) TDS for } 1 \text { month }\end{array}$ & $\begin{array}{l}\text { Patient's mouth opening and } \\
\text { burning } \\
\text { sensation on VAS }\end{array}$ & $\begin{array}{l}\text { The change in burning sensation } \\
\text { on VAS scale was statistically } \\
\text { significant, and maximum } \\
\text { improvement was observed in } \\
\text { Group B ( } 83.33 \%) \text {. The overall } \\
\text { change in mouth opening } \\
\text { was } 0.69 \mathrm{~cm} \text { which was not } \\
\text { statistically significant, with } \\
\text { maximum improvement in late } \\
\text { stages (Group D) }\end{array}$ \\
\hline 6. & Das et al. & RCT & 48 & $\begin{array}{l}\text { Group I patients was given } \\
\text { curcumin capsules, Group II } \\
\text { TO, and Group III the control } \\
\text { group was provided with } \\
\text { multinal tablets for } 3 \text { months }\end{array}$ & $\begin{array}{l}\text { Improvement of burning } \\
\text { sensation, } \\
\text { IID, and TP and H/P }\end{array}$ & $\begin{array}{l}\text { Significant improvement was } \\
\text { observed in the clinical signs and } \\
\text { symptoms of patients treated } \\
\text { with curcumin and TO when } \\
\text { compared to those with multinal }\end{array}$ \\
\hline 7. & Rai et al. & Pre-post study & $\begin{array}{l}25 \\
(100)\end{array}$ & $\begin{array}{l}\text { Curcumin } 1 \text { g caplets } \\
\text { (900 mg curcumin and } 80 \\
\text { mg desmethoxycurcumin, } \\
\text { and } 20 \text { mg } \\
\text { bisdesmethoxycurcumin) }\end{array}$ & $\begin{array}{l}\text { Pain control using VAS and } \\
\text { lesion healing measured by } \\
\text { lesion size and mouth opening } \\
\text { salivary and serum oxidative } \\
\text { markers such as MDA, } 8-0 H d G \text {, } \\
\text { and Vitamins C and E were } \\
\text { analyzed at baseline, } 1 \text { week } \\
\text { and after clinical cure of the } \\
\text { lesion }\end{array}$ & $\begin{array}{l}\text { Salivary MDA levels decreased } \\
\text { from } 0.32(0.16)-0.11 \text { and } \\
\text { serum levels decrease from } \\
1.19(0.37)-0.98(0.67) \text {. Levels } \\
\text { of } 8 \text {-OhdG showed a similar } \\
\text { decrease in salivary }(0.32-0.11) \\
\text { and serum samples }(2.12-1.89) \text {. } \\
\text { Levels of Vitamin C increased in } \\
\text { salivary samples (1.01-1.45) as } \\
\text { well as in serum (8.56-9.05. A } \\
\text { similar trend was observed in } \\
\text { Vitamin E in salivary (0.67-0.89) } \\
\text { and serum samples (8.08-8.97). } \\
\text { Mouth opening increased from } \\
24.64(3.2) \text { to } 39.4 \text { (3) mm } \\
\text { (p<0.05) }\end{array}$ \\
\hline 8. & Hastak et al. & $\begin{array}{l}\text { Observational } \\
\text { study }\end{array}$ & 90 & $\begin{array}{l}\text { Group 1: } 15 \text { patients received } \\
\text { a total of } 3 \mathrm{~g} / \text { day of } \mathrm{TE} \\
\text { in three equal doses; } 10 \\
\text { patients completed } 3 \text { months } \\
\text { treatment and served as } \\
\text { positive controls; Group } 2: 22 \\
\text { patients were given } 600 \mathrm{mg} \\
\text { TOR per day mixed in } 3 \mathrm{~g} \\
\text { of TE in three equal doses; } \\
13 \text { patients continued up to } \\
3 \text { months; and Group } 3: 21 \\
\text { patients were given } 600 \mathrm{mg} \\
\text { TO per day mixed with } 3 \mathrm{~g} \\
\text { of TE; } 16 \text { patients continued } \\
\text { up to } 3 \text { months. } 32 \text { normal } \\
\text { healthy subjects without } \\
\text { chewing and smoking habits } \\
\text { and of comparable age were } \\
\text { studied for comparison with } \\
\text { the treatment groups }\end{array}$ & $\begin{array}{l}\text { Number of micronucleated } \\
\text { cells in exfoliated oral } \\
\text { mucosal cells and circulating } \\
\text { lymphocytes }\end{array}$ & $\begin{array}{l}\text { Number of micronuclei/100 } \\
\text { cells in exfoliated buccal } \\
\text { mucosal cells in normal } \\
\text { patients was } 2.2 \pm 0.17 \text { and } \\
10.2 \pm 0.28 \text { in OSMF patients. } \\
\text { This decreased to } 3.9 \pm 0.23 \text { in } \\
\text { patients of Group } 1,3.8 \pm 0.23 \\
\text { in patients of Group } 2 \text {, and } \\
2.7 \pm 0.22 \text { in patients of Group } 3 . \\
\text { A similar trend was observed } \\
\text { in micronuclei/100 cells in } \\
\text { circulating lymphocytes }\end{array}$ \\
\hline
\end{tabular}

OSMF: Oral submucous fibrosis, SOD: Superoxide dismutase, VAS: Visual analogue scale, IID: Interincisal distance, TP: Tongue protrusion, 8-OHdG: 8-hydroxydeoxyguanosine MDA: Malondialdehyde, TOR: Turmeric oleoresin, RCT: Randomized control trial, TO: Turmeric oil 
In the study by Yadav et al., complete, rapid, and early improvement of burning sensation was observed with curcumin compared to a mean $15.6 \%$ residual burning sensation at the end of therapy in the steroid group [26]. Improvement in mouth opening and tongue protrusion was less as compared to intralesional steroids. The authors recommended that early use of curcumin in OSMF patients provides rapid symptomatic relief and, therefore, is beneficial and effective in the management of early OSMF. Similar results have been obtained by Srivastava et al. who reported significant improvement in burning sensation only, not mouth opening, in OSMF patients following treatment with curcumin [25]. In their study, maximum improvement in mouth opening was observed in the late stage while maximum improvement in burning sensation was observed in early stages.

The study by Das et al. compared curcumin, turmeric oil (TO), and multinal tablets and found that curcumin produced a quicker reduction in burning sensation and intolerance to spicy food, though TO was found to have a long-term effect on follow-up evaluation [27]. Complete relief of pain was reported with both curcumin and TO, while pain persisted in 5 patients in the multinal group. Statistically significant and equal increase in mouth opening of patients in Groups I and II was observed. The remarkable reduction in clinical scoring after 15 days of treatment with curcumin and TO was observed and was confirmed histopathologically as well. They also reported that curcumin and TO were well-tolerated without adverse events.

The study by Rai et al. studied 25 patients each of OSMF, oral leukoplakia, and OLP and 25 controls and assessed oxidative stress markers in serum and saliva [28]. The mean and median values of serum and salivary Vitamins $\mathrm{C}$ and $\mathrm{E}$ showed an increase, while malondialdehyde (MDA) and 8-hydroxydeoxyguanosine (8-OHdG) levels showed decreases in OSMF patients 1 week after intake of curcumin. These values were statistically significant after curing of OSMF in an average of 211 (17) days. A similar trend of increase in Vitamins $\mathrm{C}$ and $\mathrm{E}$ levels and a decrease of MDA and 8-OHdG levels were observed when the comparison of OSMF patients with healthy controls was made, at baseline and after 209 days. Improvement in pain scores, size of the lesion, and mouth opening was also significant. This research suggested that curcumin significantly increases the local and systemic antioxidant status and the levels of Vitamins $\mathrm{C}$ and $\mathrm{E}$, while it decreases the lipid peroxidation and DNA damage of patients with potentially malignant disorders. Curcumin quenches reactive oxygen species (ROS) production at low concentrations and induces ROS production at high concentration

Hastak et al. did a combination of in vitro and in vivo study in OSMF patients and showed that there is increased the incidence of micronuclei (Mn) in exfoliated oral mucosal cells and circulating lymphocytes of patients suffering from OSMF [29]. In this study, the authors report nonmutagenicity of TO and turmeric oleoresin (TOR) on the basis of the fact that TO and TOR did not induce an increase in Mn in lymphocytes when treated individually. They also report the chemoprotective effect of TO and TOR in lymphocytes of normal healthy subjects in vitro and recovery from DNA damage in OSMF patients in vivo.

\section{Curcumin in oral leukoplakia}

According to the World Health Organization (WHO) workshop consensus "the term leukoplakia should be used to recognize white plaques of questionable risk having excluded (other) known diseases or disorders that carry no risk for cancer" [30]. Oral leukoplakia is the most commonly encountered oral potentially malignant disorder and presents as homogenous form and non-homogeneous forms [31].

Curcumin suppresses mutagenesis and has been used as a chemopreventive agent in a variety of cancers including those arising in the oral cavity [32]. Several mechanisms are involved in the prevention of carcinogenesis by curcumin. It involves upregulation of carcinogendetoxifying enzymes such as glutathione S-transferases [33,34] antioxidation $[35,36]$, and suppression of expression of the isoenzyme cyclooxygenase-2 $[37,38]$. It shows greater modulation of translational mechanism in immortalized normal, premalignant, and malignant cells as compared to normal cells [39].

Review of existing literature shows that apart from the study by Rai et al. [28] which also included 25 oral leukoplakia patients, two other reports have studied the effect of curcumin on oral leukoplakia (Table 2).

A prospective phase-I study was conducted to evaluate the biologically effective dose of curcumin in humans and study the toxicology and pharmacokinetics of curcumin [40]. Patients with five highrisk conditions, namely recently resected urinary bladder cancer, arsenic Bowen's disease of the skin, uterine cervical intraepithelial neoplasm, oral leukoplakia, and intestinal metaplasia of the stomach, were recruited. Curcumin was administered orally in 25 patients for 3 months at a starting dose of $500 \mathrm{mg} /$ day. The dose was escalated to a higher level up to $12,000 \mathrm{mg} /$ day if no toxicity $\geq$ Grade II was noted in at least three successive patients. Results after 3 months showed the histological improvement of precancerous lesions in 1 of 2 patients with recently resected bladder cancer, 2 of 7 patients of oral leukoplakia, 1 of 6 patients of intestinal metaplasia of the stomach, 1 of 4 patients with contrast-induced nephropathy (CIN), and 2 of 6 patients with Bowen's disease suggesting role of curcumin in chemoprevention. One patient with CIN and another with oral leukoplakia developed frank malignancies even after receiving curcumin treatment. No treatmentrelated toxicity up to the dose of $8000 \mathrm{mg} /$ day was reported. The bulky volume of the drug was a deterrent to the patients on giving higher dosage.

In an intervention study from Sri Lanka, 72 betel quid chewers with oral potentially malignant lesions were randomly divided into two groups and were given either curcumin-coated chewing gum or placebo chewing gum [41]. The patients were followed every month while the sizes of lesions were measured every 6 months. The results showed that oral potentially malignant lesions of the curcumin group were significantly smaller within 6 months $(\mathrm{p}<0.05)$ and quitting betel quid chewing, and the use of curcumin had synergistic effects on the reduction of the lesion size.

\section{Curcumin in treating palatal changes associated with reverse smoking}

The term "palatal changes" describes the reaction of the palatal mucosa to reverse chutta smoking, a form of smoking more prevalent among females of Andhra Pradesh [42]. It encompasses several entities such as palatal keratosis, excrescences, altered pigmentation, erythematous areas, white or mixed red and white patches, and palatal ulcers. The study by Vijayalaxmi et al. evaluates the efficacy of curcumin preparation on the palatal changes associated with reverse smoking in 20 patients [43]. The study group was advised to use curcumin oral gel on an acrylic palatal plate along with instructions to quit smoking whereas control group patients were instructed about the benefits of smoking cessation only. Clinical and cytological smear examinations were performed for three visits at 15 days interval. Clinical improvement was graded as mild ( $1 / 4$ reduction in the clinical presentation), moderate ( $1 / 2$ reduction in the clinical presentation), and fully improved if there was no evidence of the clinical lesion or no improvement if the lesion was persisting as it was. Evident improvement with reduction in size and severity of the clinical lesion was observed among the study group at both the first and third visits. However, the cytological appearances remained the same in all the cases, except for three cases from the study group, which demonstrated a transition from moderate dysplastic features to milder dysplastic features.

\section{Curcumin on OLP}

OLP is an immunologically mediated mucocutaneous disorder. Lichen planus affects the skin, oral mucosa, nail, genital mucosa, and scalp [44]. Skin lesions are classically described as purple, pruritic, and polygonal papules usually affecting the flexor surface of extremities [45]. Oral 
Table 2: Review of literature showing three research papers assessing the efficacy of curcumin in oral leukoplakia patients

\begin{tabular}{|c|c|c|c|c|c|c|}
\hline S. No. & Author(s) & Type of evidence & $\mathbf{n}$ & Interventions & Outcomes & Results \\
\hline 1. & Cheng et al. & $\begin{array}{l}\text { Phase I clinical } \\
\text { trial }\end{array}$ & $25(7)$ & $\begin{array}{l}\text { The starting dose was } \\
500 \mathrm{mg} / \text { day for } 3 \text { months. } \\
\text { If no toxicity } \geq \text { Grade II } \\
\text { was noted in at least three } \\
\text { successive patients, the } \\
\text { dose was then escalated to } \\
\text { another level in the order } \\
\text { of } 1000,2000,4000,8000 \text {, } \\
\text { and } 12,000 \mathrm{mg} / \text { day }\end{array}$ & $\begin{array}{l}\text { The concentration of } \\
\text { curcumin in serum and } \\
\text { urine was determined } \\
\text { by high-pressure liquid } \\
\text { chromatography. } \\
\text { Biopsy of the lesion sites } \\
\text { was done immediately } \\
\text { before and } 3 \text { months } \\
\text { after starting curcumin } \\
\text { treatment }\end{array}$ & $\begin{array}{l}\text { The average peak serum } \\
\text { concentrations after taking } \\
4000 \mathrm{mg}, 6000 \mathrm{mg} \text {, and } \\
8000 \mathrm{mg} \text { of curcumin were } \\
0.51 \pm 0.11 \mu \mathrm{M}, 0.63 \pm 0.06 \mu \mathrm{M} \text {, } \\
\text { and } 1.77 \pm 1.87 \mu \mathrm{M} \text {, } \\
\text { respectively. Urinary excretion } \\
\text { of curcumin was undetectable. } \\
1 \text { of } 4 \text { patients with CIN and } \\
1 \text { of } 7 \text { patients with oral } \\
\text { leukoplakia proceeded to } \\
\text { develop frank malignancies in } \\
\text { spite of curcumin treatment. } \\
\text { Histologic improvement of } \\
\text { precancerous lesions was } \\
\text { seen in } 2 \text { of } 7 \text { patients of oral } \\
\text { leukoplakia }\end{array}$ \\
\hline 2. & Chiba et al. & RCT & 72 & $\begin{array}{l}\text { Curcumin-coated chewing } \\
\text { gum and placebo chewing } \\
\text { gum }\end{array}$ & $\begin{array}{l}\text { The sizes of lesions } \\
\text { were measured every } \\
6 \text { months }\end{array}$ & $\begin{array}{l}\text { The oral precancerous lesions } \\
\text { of the curcumin group were } \\
\text { significantly smaller within } \\
6 \text { months }(\mathrm{p}<0.05) \text {. Quitting } \\
\text { betel quid chewing and the use } \\
\text { of curcumin had synergistic } \\
\text { effects on the reduction of the } \\
\text { lesion size }(\mathrm{p}<0.05)\end{array}$ \\
\hline 3. & Rai et al. & Pre-post study & $25(100)$ & $\begin{array}{l}\text { Curcumin } 1 \text { g caplets } \\
\text { ( } 900 \text { mg curcumin, } 80 \mathrm{mg} \\
\text { desmethoxycurcumin, } \\
\text { and } 20 \mathrm{mg} \\
\text { bisdesmethoxycurcumin) }\end{array}$ & $\begin{array}{l}\text { Pain control using VAS } \\
\text { and lesion healing } \\
\text { measured by lesion size } \\
\text { and mouth opening } \\
\text { salivary and serum } \\
\text { oxidative markers such } \\
\text { as MDA, 8-OHdG, and } \\
\text { Vitamins C and E were } \\
\text { analyzed at baseline, } 1 \\
\text { week and after clinical } \\
\text { cure of the lesion }\end{array}$ & $\begin{array}{l}\text { Salivary MDA levels decreased } \\
\text { from } 0.32(0.16) \text { to } 0.11 \text { and } \\
\text { serum levels decrease from } \\
1.19(0.37) \text { to } 0.98 \text { (0.67). } \\
\text { Levels of } 8 \text {-OhdG showed a } \\
\text { similar decrease in salivary } \\
(0.32-0.11) \text { and serum samples } \\
(2.12-1.89) \text {. Levels of Vitamin } \\
\text { C increased in salivary samples } \\
(1.01-1.45) \text { as well as in serum } \\
(8.56-9.05) \text {. A similar trend } \\
\text { was observed in Vitamin E in } \\
\text { salivary (0.67-0.89) and serum } \\
\text { samples (8.08-8.97). Mouth } \\
\text { opening increased from } 24.64 \\
\text { (3.2) to } 39.4(3) \text { mm (p<0.05) }\end{array}$ \\
\hline
\end{tabular}

CIN: Contrast-induced nephropathy, MDA: Malondialdehyde, 8-OHdG: 8-hydroxydeoxyguanosine, RCT: Randomized control trial

lesions can present as reticular, erosive, atrophic, plaque-like, popular, or bullous type [46]. Reticular lichen planus is associated with better prognosis [47]. The occurrence and distribution of lesion in the oral mucosa are $80 \%$ in the buccal mucosa, $65 \%$ in the tongue, $20 \%$ lips, and $<10 \%$ seen in the floor of mouth and palate [48]. The follow-up studies of OLP reveal the malignant transformation of this condition to be up to $5.3 \%$ [49].

The review of the literature reveals five research papers which have been published assessing the efficacy of curcumin in OLP patients (Table 3). Of these, three have been authored by Chainani-Wu et al. [50]. First was a phase-II randomized, double-blind, and placebo-controlled trial evaluating the efficacy and safety of curcuminoids as an adjunct to short-course corticosteroids for the treatment of patients with atrophic or erosive OLP. The trial was conducted between February 2003 and September 2004, curcuminoids at $2000 \mathrm{mg}$ /day for 7 weeks and prednisone at $60 \mathrm{mg} /$ day for the first 1 week were given. The first interim analysis conducted in October 2004 using data from the first 33 subjects did not show a significant difference between the placebo and curcuminoids groups. Therefore, the study was ended early for futility. The initial course of prednisone was used in this trial due to ethical concerns regarding a placebo-controlled trial extending for 7 weeks among patients with significant oral discomfort. It was concluded that an RCT of a shorter duration, using a higher dose of curcuminoids without an initial course of prednisone, should be considered.

As a next step, randomized, double-blind, and placebo-controlled clinical trial were conducted in 2007 through 2008 with 20 patients of OLP [51]. Curcuminoids at doses of $6000 \mathrm{mg} /$ day (3 divided doses) were given, and the curcuminoids group showed a greater reduction in clinical signs and symptoms as compared with the placebo group. Although the small sample size resulted in the limited power of the study, curcuminoids at doses of $6000 \mathrm{mg} /$ day in 3 divided doses are well-tolerated.

In their third paper, the authors summarized the long-term openlabel use of curcuminoids and experience of side effects (SEs) in 53 patients with OLP who had previously participated in RCTs of curcuminoids [52]. Of the 53 eligible patients, data were available for $44(25 / 33)(75 \%)$ from the first and 19/20 (95\%) from the second RCT. 18/25 participants from the first trial and 19/19 from the second trial took over-the-counter curcuminoids after completion of the trial period. The mean total daily dose was $2137.5 \mathrm{mg}$ for $18 / 25$ patients and $5058 \mathrm{mg}$ for the $19 / 19$ patient group. $10 / 18$ (56\%) reported that 
Table 3: Review of literature showing five research papers assessing the efficacy of curcumin in OLP patients

\begin{tabular}{|c|c|c|c|c|c|c|}
\hline S. No. & Author(s) & $\begin{array}{l}\text { Type of } \\
\text { evidence }\end{array}$ & $\mathbf{n}$ & Interventions & Outcomes & Results \\
\hline 1. & $\begin{array}{l}\text { Chainani- } \\
\text { Wua et al. }\end{array}$ & RCT & 100 & $\begin{array}{l}\text { Study subjects were } \\
\text { randomized to receive } \\
\text { either placebo or } \\
\text { curcuminoids at } \\
2000 \mathrm{mg} / \text { day for } 7 \text { weeks. } \\
\text { In addition, all subjects } \\
\text { received prednisone at } \\
60 \mathrm{mg} / \text { day for the first } 1 \\
\text { week }\end{array}$ & $\begin{array}{l}\text { The primary outcome } \\
\text { was a change in symptom } \\
\text { score from the baseline } \\
\text { to the last follow-up visit } \\
\text { at week } 7 . \text { Secondary } \\
\text { endpoints included } \\
\text { changes in symptom } \\
\text { scores from baseline } \\
\text { at weeks } 1 \text { and } 4 \text {, and } \\
\text { changes in clinical signs } \\
\text { from baseline at weeks } \\
\text { 1, } 4 \text {, and } 7 \text {, as well as the } \\
\text { occurrence of adverse } \\
\text { effects. Five assessments } \\
\text { - VAS, NRS, CSS, MOMI, } \\
\text { and SEs (10-item } \\
\text { questionnaire) were at } 0 \text {, } \\
1,4 \text {, and } 7 \text { weeks }\end{array}$ & $\begin{array}{l}\text { The first interim analysis } \\
\text { ( } 33 \text { patients) did not show } \\
\text { a significant difference } \\
\text { between the placebo and } \\
\text { curcuminoids groups. The } \\
\text { changes in NRS values from } \\
\text { baseline to } 7 \text { weeks in the } \\
\text { placebo and curcuminoids } \\
\text { groups were - } 1.996 \text { and } \\
\text {-1.666, respectively; changes } \\
\text { in VAS values were - } 19.743 \\
\text { and -15.476, respectively; and } \\
\text { changes } \\
\text { in MOMI values were - } 2.8 \text { and } \\
\text { - } 3.583 \text {, respectively }\end{array}$ \\
\hline 2. & $\begin{array}{l}\text { Chainani- } \\
\text { Wua et al. }\end{array}$ & RCT & 20 & $\begin{array}{l}\text { Study subjects were } \\
\text { randomized to receive } \\
\text { either placebo or } \\
\text { curcuminoids at } \\
6000 \mathrm{mg} / \text { day }\end{array}$ & $\begin{array}{l}\text { Measurement of } \\
\text { symptoms and signs of } \\
\text { OLP using NRS and MOMI, } \\
\text { CBC, liver enzymes; } \\
\text { C-reactive protein; and } \\
\text { IL-6 levels were done at } \\
\text { baseline and day } 14\end{array}$ & 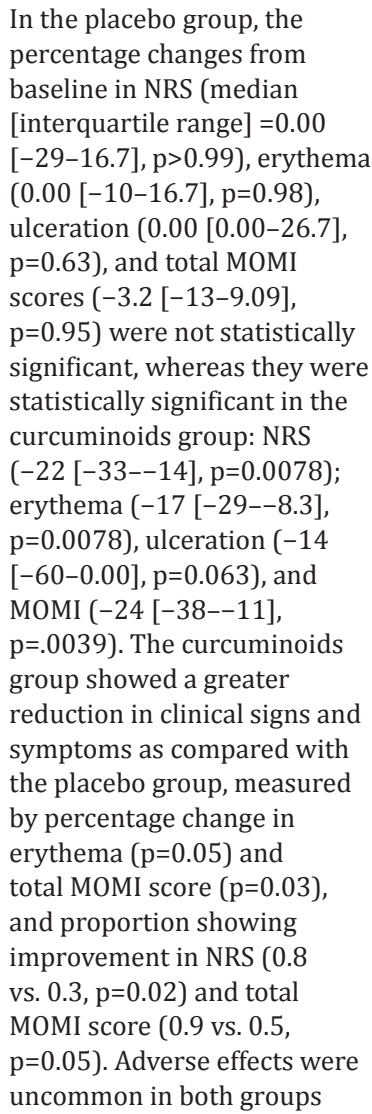 \\
\hline 3. & $\begin{array}{l}\text { Chainani- } \\
\text { Wua et al. }\end{array}$ & $\begin{array}{l}\text { A descriptive } \\
\text { retrospective } \\
\text { cohort study }\end{array}$ & $\begin{array}{l}44(25 / 33 \\
{[75 \%] \text { from }} \\
\text { the first and } \\
19 / 20[95 \%] \\
\text { from the } \\
\text { second RCT) }\end{array}$ & $\begin{array}{l}\text { Collected information from } \\
\text { clinic charts and patient } \\
\text { interview on the OTC use of } \\
\text { curcuminoids during a 1-5- } \\
\text { year follow-up period }\end{array}$ & $\begin{array}{l}18 / 25(72 \%) \text { participants } \\
\text { from the first trial - mean } \\
\text { total daily dose was } \\
2137.5 \mathrm{mg}(\mathrm{SD}=793 \text {, } \\
\text { range } 500-3000 \mathrm{mg}) \text { and } \\
\text { mean duration of use was } \\
30 \text { months }(\mathrm{SD}=27.5) \text {. } \\
19 / 19(100 \%) \text { patients } \\
\text { from the second trial - } \\
\text { mean total daily dose was } \\
5058 \text { mg (SD=1445, range } \\
1000-6000 \mathrm{mg}) \text { and } \\
\text { mean duration was } 9.6 \\
\text { months (SD=8.04) }\end{array}$ & $\begin{array}{l}10 / 18(56 \%) \text { reported that } \\
\text { curcuminoids } \\
\text { controlled OLP symptoms, } \\
\text { mean duration - } 35.8 \text { months } \\
(\mathrm{SD}=27.4) .8 / 18(44 \%) \text { - } \\
\text { unsure, mean duration of use } \\
\text { was } 21.0 \text { months }(\mathrm{SD}=27.3) \text {. } \\
2 / 18 \text { patients }(11 \%) \text { reported } \\
\text { a SE of diarrhea }\end{array}$ \\
\hline
\end{tabular}


Table 3: (Continued)

\begin{tabular}{|c|c|c|c|c|c|c|}
\hline S. No. & Author(s) & $\begin{array}{l}\text { Type of } \\
\text { evidence }\end{array}$ & $\mathbf{n}$ & Interventions & Outcomes & Results \\
\hline 4. & Rai et al. & $\begin{array}{l}\text { Pre-post } \\
\text { study }\end{array}$ & $25(100)$ & $\begin{array}{l}\text { Curcumin } 1 \text { g caplets } \\
\text { ( } 900 \mathrm{mg} \text { curcumin, } 80 \mathrm{mg} \\
\text { desmethoxycurcumin, } \\
\text { and } 20 \mathrm{mg} \\
\text { bisdesmethoxycurcumin) }\end{array}$ & $\begin{array}{l}\text { Pain control using VAS } \\
\text { and lesion healing } \\
\text { measured by lesion size } \\
\text { and mouth opening } \\
\text { salivary and serum } \\
\text { oxidative markers such } \\
\text { as MDA, 8-OHdG, and } \\
\text { Vitamins C and E, were } \\
\text { analyzed at baseline, } \\
1 \text { week and after clinical } \\
\text { cure of the lesion }\end{array}$ & $\begin{array}{l}\text { Salivary MDA levels decreased } \\
\text { from } 0.32(0.16) \text { to } 0.11 \\
\text { and serum levels decrease } \\
\text { from } 1.19(0.37) \text { to } 0.98 \\
(0.67) \text {. Levels of } 8-0 \text { hdG } \\
\text { showed a similar decrease } \\
\text { in salivary }(0.32-0.11) \text { and } \\
\text { serum samples }(2.12-1.89) \text {. } \\
\text { Levels of Vitamin C increased } \\
\text { in salivary samples (1.01- } \\
1.45) \text { as well as in serum } \\
(8.56-9.05) \text {. A similar trend } \\
\text { was observed in Vitamin E } \\
\text { in salivary }(0.67-0.89) \text { and } \\
\text { serum samples (8.08-8.97). } \\
\text { Mouth opening increased } \\
\text { from } 24.64(3.2) \text { to } \\
39.4(3) \text { mm (p<0.05) }\end{array}$ \\
\hline 5. & Singh et al. & Pilot study & 10 & $\begin{array}{l}\text { Extract of turmeric in the } \\
\text { ointment form was made } \\
\text { at NBRI, used for local } \\
\text { application twice/day for a } \\
\text { period of } 3 \text { months }\end{array}$ & $\begin{array}{l}\text { Reduction in sign score } \\
\text { (Thongprasom), pain } \\
\text { score (VAS) lesion before } \\
\text { and after treatment }\end{array}$ & $\begin{array}{l}\text { Sign score was } 5 \text { in } 8 \text { patients } \\
\text { and } 4 \text { in } 2 \text { patients initially } \\
\text { which changed to score } 0 \text { in } \\
9 \text { patients and } 1 \text { in } 1 \text { patient. } \\
\text { Initially, pain on VAS for all } 10 \\
\text { patients was between } 2 \text { and } 4 \\
\text { which changed to } 0-2 \text { after the } \\
\text { treatment }\end{array}$ \\
\hline
\end{tabular}

RCT: Randomized control trial, CSS: Change in symptoms scale, MOMI: Modified oral mucositis index, OLP: Oral lichen planus, VAS: Visual analogue scale, CBC: Complete blood count, IL-6: Interleukin-6, NRS: Numeric rating scale, OTC: Over-the-counter, SD: Standard deviation, SE: Side effect

curcuminoids controlled OLP symptoms, and the mean duration of use among these patients was 35.8 months. $12 / 19$ (63\%) reported that curcuminoids controlled OLP symptoms, and the mean duration of use was 14.1 months. It was concluded that total of $22 / 37(60 \%)$ of patients reported a reduction of symptoms with curcuminoids, 13/37 (35\%) were unsure and 2/37 (5\%) reported that it did not help in reduction of symptoms. SEs included abdominal discomfort and diarrhea; however, the occurrence was dose-related, and complaints were mild.

Rai et al. [28] studied 25 patients each of OSMF, oral leukoplakia, and OLP, and 25 controls and proved that anti-precancerous effects of curcumin are mediated through prooxidant and antioxidant pathways.

In a pilot study, topical application of curcuminoids was studied on 10 patients of OLP [53]. The extract of turmeric in the ointment form was used for local application twice/day for a period of 3 months. Significant improvement was noted in the signs and symptoms in the follow-up period. It was suggested that curcumin has an immune modulatory effect which could prove beneficial in the management of this cell-mediated autoimmune disorder.

\section{Curcumin in RAS}

RAS is a common condition characterized by the presence of recurring oval or round ulcerative lesions affecting oral mucosa [54]. Multifactorial etiology has been proposed involving various predisposing factors such as stress, trauma, food, hormonal imbalance, nutritional deficiency, and smoking [55]. RAS has been classified by Stanley in three variants - minor RAS, major RAS, and herpetiform ulceration [56].

The possible mechanism of action of the curcumin in RAS involves the decreased rate of release and metabolism of arachidonic acid, leading to diminished activities of phospholipase A2, cyclooxygenase, and lipoxygenase [57]. Previous studies show that curcumin could downregulate the expression of cytokines such as interleukin (IL)-6, TNF- $\alpha$, and various other chemokines. Thus, curcumin suppresses inflammation through multiple pathways [58]. Animal studies have shown that oral administration of curcumin in instances of acute inflammation was found to be equally effective as cortisone or phenylbutazone and half as effective in cases of chronic inflammation [59]. The activity of curcumin in acute ulcer model in rats has been studied [60]. It causes re-epithelization and accelerated the healing process and protected gastric ulcer through attenuation of MMP-9 activity and amelioration of MMP-2 activity. In an animal study, curcumin increased cellular proliferation and collagen synthesis at the wound site [61]. An immunohistochemical study evaluating the impact of curcumin on oral ulcer healing in rats proved that administration of curcumin in normal rats with tongue ulcer leads to increased expression of TGF- $\beta$ and increased expression of $\alpha$ SMA associated with increased migration of epithelial cells, which lead to smaller ulcer size in the first 9 days [62]. Thorat et al. have formulated a thermoreversible mucoadhesive gel containing curcumin for the treatment of mouth ulcer and characterized it [63].

A literature search for use of curcumin in RAS patients revealed five trials, of which four are RCT, and one is a controlled study (Table 4).

Deshmukh et al. [64] compared the efficacy of curcumin with triamcinolone acetonide in the gel form in the treatment of minor RAS. Their study showed that there was a significant difference between the pain score, size, number, and duration of ulcers from day 0 to day 7 in both the groups, respectively. Statistical significance was not noted between all the parameters when both the groups were compared with each other. The results of this study provide positive evidence that curcumin gel can be used as an effective and safer alternative to steroids in the treatment of minor RAS. A similar study comparing turmeric and triamcinolone was conducted by Halim et al. [65]. There were significant differences in the pain score and ulcer size on days 1 and 5 in both the groups, but there is no significant difference between turmeric and triamcinolone for the treatment of minor RAS. Even though the differences were not significant, for mean comparison, the 
Table 4: Review of literature showing five research papers assessing the efficacy of curcumin in recurrent aphthous ulcer patients

\begin{tabular}{|c|c|c|c|c|c|c|}
\hline S. No. & Author(s) & $\begin{array}{l}\text { Type of } \\
\text { evidence }\end{array}$ & $\mathbf{n}$ & Interventions & Outcomes & Results \\
\hline 1. & Deshmukh et al. & RCT & 60 & $\begin{array}{l}\text { Group I - Curcumin gel group } \\
\text { (10 mg of } C \text {. longa extract/g) and } \\
\text { Group II - triamcinolone } \\
\text { acetonide }(0.1 \%) \text { gel group } \\
\text { patients in either group were } \\
\text { asked to apply the gel } 3 \text { times a } \\
\text { day on each ulcer }\end{array}$ & $\begin{array}{l}\text { Ulcer size measured } \\
\text { along its longest } \\
\text { diameter, number of } \\
\text { ulcers, duration of } \\
\text { healing, and pain score } \\
\text { was } 0-10 \text { using the VAS } \\
\text { on day } 0,3,5 \text {, and } 7\end{array}$ & $\begin{array}{l}\text { Reduction in pain ( } 4.7 \pm 1.53 \\
\text { in Group I and } 4.5 \pm 1.43 \text { in } \\
\text { Group II), size } \\
(-3.8 \pm 1.08 \text { in Group I and } \\
-3.7 \pm 1.53 \text { in Group II), and } \\
\text { the number of ulcers } \\
(-1.2 \pm 0.38 \text { in Group I and } \\
-1.5 \pm 0.77 \text { in Group II) and } \\
\text { duration of ulcers } \\
(3.9 \pm 1.18 \text { in Group I and } \\
4.1 \pm 1.18 \text { in Group II) was } \\
\text { statistically significant in } \\
\text { both the groups from day } 0 \\
\text { to day } 7, \text { respectively; but } \\
\text { on the comparison between } \\
\text { Groups I and II, no statistical } \\
\text { significance was noted }\end{array}$ \\
\hline 2. & Halim et al. & RCT & 20 & $\begin{array}{l}\text { Group I received turmeric } \\
\text { powder, and Group II received } \\
\text { triamcinolone acetonide, to be } \\
\text { applied for } 5 \text { min twice per day }\end{array}$ & $\begin{array}{l}\text { The VAS has been used } \\
\text { to assess the pain score, } \\
\text { and the ulcer size was } \\
\text { measured by sliding } \\
\text { caliper on day } 1 \text { and } 5\end{array}$ & $\begin{array}{l}\text { The statistically significant } \\
\text { difference in reduction in pain } \\
\text { score from day } 1(4.40 \pm 1.713) \\
\text { to } 5(0.80 \pm 2.530) \text { in } \\
\text { Group II and the Group I } \\
(5.7 \pm 1.767 \text { day } 1 ; 1.1 \pm 1.287 \\
\text { day } 5) \text { was observed. A } \\
\text { similar difference in size } \\
\text { of the ulcer for the Group I } \\
\text { (mean } 23.7042 \pm 82.05465) \\
\text { and Group II (mean } \\
51.4677 \pm 60.71060) \text { were } \\
\text { observed. No significant } \\
\text { difference between turmeric } \\
\text { and triamcinolone for the } \\
\text { treatment of minor recurrent } \\
\text { aphthous ulcer observed }\end{array}$ \\
\hline 3. & Manifer et al. & RCT & 57 & $\begin{array}{l}\text { Group I received placebo gel, and } \\
\text { Group II received curcumin gel } \\
2 \% \text {, to be applied twice per day }\end{array}$ & $\begin{array}{l}\text { Size of ulcers } \\
\text { measured by the } \\
\text { investigator, pain } \\
\text { evaluated based on } \\
\text { perceived } \\
\text { pain rating scale before } \\
\text { drug application (day } \\
0 \text { ) and at days } 4,7 \text {, and } \\
14 \text { as well as subject } \\
\text { overall satisfaction score } \\
\text { at the end of } \\
\text { treatment on four- } \\
\text { point description scale } \\
\text { (poor }=1 \text {, moderate=2, } \\
\text { good=3, and } \\
\text { excellent }=4 \text { ) }\end{array}$ & $\begin{array}{l}\text { Mean ulcer pain of } \\
\text { two groups matched well at } \\
\text { baseline but was significantly } \\
\text { relieved in the turmeric group } \\
\text { at day } 4 \text { ( } \mathrm{p}<0.05 \text { ). Ulcer size } \\
\text { of the treatment group and } \\
\text { the placebo group matched } \\
\text { well at } \\
\text { the study entry (p }>0.05 \text { ), } \\
\text { significant group differences } \\
\text { appeared at the later visits } \\
\text { (days } 4 \text { and } 7 ; p<0.05 \text { ). Highly } \\
\text { significant group differences } \\
\text { appeared at } \\
\text { the end of the trial regarding } \\
\text { the overall satisfaction of the } \\
\text { patients ( } \leq \leq 0.01 \text { ) }\end{array}$ \\
\hline 4. & $\begin{array}{l}\text { Antharjanam } \\
\text { and Balan }\end{array}$ & $\begin{array}{l}\text { Controlled } \\
\text { trial }\end{array}$ & 20 & $\begin{array}{l}\text { Group I - antiseptic gel topically } \\
\text { twice daily. Group II - instructed } \\
\text { to hold } 2.5 \mathrm{ml} \text { of curcumin oil } \\
\text { ( } 1 \mathrm{ml} \text { of curcumin oil contained } \\
250 \mathrm{mg} \text { curcumin) mixed with } \\
10 \mathrm{ml} \text { of milk for } 1-2 \text { min and } \\
\text { spit, twice daily }\end{array}$ & $\begin{array}{l}\text { The number of ulcers, } \\
\text { the intensity of pain, the } \\
\text { period of healing and } \\
\text { frequency of recurrence } \\
\text { through log diaries given } \\
\text { to the patient. Pain was } \\
\text { assessed using } \\
\text { VAS }\end{array}$ & $\begin{array}{l}\text { Patients who used curcumin } \\
\text { oil reported that ulcers } \\
\text { started healing earlier than } \\
\text { in previous attacks; there } \\
\text { was also an early reduction } \\
\text { in pain. A follow up for } 1 \text { year } \\
\text { has shown no recurrence in } \\
\text { these patients }\end{array}$ \\
\hline
\end{tabular}


Table 4: (Continued)

\begin{tabular}{|c|c|c|c|c|c|c|}
\hline S. No. & Author(s) & $\begin{array}{l}\text { Type of } \\
\text { evidence }\end{array}$ & $\mathbf{n}$ & Interventions & Outcomes & Results \\
\hline 5. & Al-Saffar & RCT & 83 & $\begin{array}{l}\text { Group A: } 30 \text { patients received } \\
\text { a viscous solution of curcumin } \\
\text { 10\%; Group B: } 33 \text { patients } \\
\text { received a viscous solution of } \\
\text { curcumin } 50 \% \text {; Group C: } 10 \\
\text { patients without treatment } \\
\text { (control negative); and Group } \\
\text { D: } 10 \text { patients received glycerin } \\
\text { treatment (control positive) }\end{array}$ & $\begin{array}{l}\text { Healing time and } \\
\text { symptomatic relief of } \\
\text { individual treatment. } \\
\text { Appearance of lesion, } \\
\text { zone of inflammation and } \\
\text { pain was recorded at each } \\
\text { visit during the } \\
\text { healing phase }\end{array}$ & $\begin{array}{l}\text { There was a significant } \\
\text { difference in the percentage } \\
\text { of complete healing between } \\
\text { control negative group and } \\
\text { groups of patients using a } \\
\text { viscous solution of curcumin } \\
10 \% \text { and } 50 \% \text { (p<0.05), } \\
\text { and there was a significant } \\
\text { difference in the percentage of } \\
\text { complete } \\
\text { healing between control } \\
\text { positive group, groups of } \\
\text { patients using a viscous } \\
\text { solution of curcumin } 10 \% \text { and } \\
\text { those using } \\
\text { viscous solution of curcumin } \\
50 \% \text { (p<0.05). While there is } \\
\text { no significant difference } \\
\text { between groups of patients } \\
\text { using a viscous solution of } \\
\text { curcumin } 10 \% \text { of those using } \\
\text { a viscous solution of curcumin } \\
50 \% \text { (p }>0.05 \text { ) }\end{array}$ \\
\hline
\end{tabular}

triamcinolone had a greater value of mean for ulcer size, indicating turmeric was better in reducing the size of the ulcer. Similarly, for pain score, turmeric was the better medicament for relieving the pain of the ulcer compared to triamcinolone.

In a randomized, double-blind, and placebo-controlled trial of patients with minor RAS efficacy of curcumin gel containing $2 \%$, curcumin was studied [66]. Curcumin gel significantly reduced pain intensity and size of aphthous ulcer compared to placebo. Significant group differences were also observed at the end of the trial regarding overall satisfaction of the patients. A study focusing on the therapeutic effects of curcumin in RAS in comparison to conventional antiseptic gel found that curcumin could produce a remarkable reduction in recurrence of RAS (follow-up for 1 year) [67]. In addition, ulcers treated with curcumin healed faster and were associated with early relief in pain.

Al-Saffar [68] studied the efficacy of two different concentrations of the viscous curcumin solution on the healing of ulcer in patients with RAS and compared it with a positive and negative control. Complete recovery occurred from 5 days (73\% patients in curcumin solution $10 \%$ and $78.7 \%$ in curcumin solution $50 \%$ ) to 11 days (6.6\% in curcumin solution $10 \%$ and $3.2 \%$ in curcumin solution $50 \%$ ). However, in control negative group (without treatment), the complete recovery occurred from 5 days (20\%) to 11 days (40\%) only. In control positive group (received glycerin vehicle treatment), the complete recovery occurred from 5 days (30\%) to 11 days (20\%).

\section{Curcumin in oral mucositis}

Oral mucositis refers to erythematous and ulcerative lesions of the oral mucosa observed in patients treated with chemotherapy, and/or with radiation therapy to fields involving the oral cavity. Lesions of oral mucositis are extremely painful and compromise nutrition and oral hygiene, thereby increase the risk for local and systemic infection [69]. Fractionated radiation dosage increases the risk of mucositis to $>70 \%$ of patients in most trials [70].

The pathophysiology of mucositis is multifarious and involves direct cellular effects brought about by DNA damage and generation of ROS. Amplification of signaling pathways, for example, TNF- $\alpha$ release, NF- $\kappa$ B activation, and ROS potentiates cell death, mediating mucosal damage. Polymicrobial flora in the oral cavity potentiates proinflammatory cytokine release [71]. Curcumin offers potential preventive and therapeutic benefit in oral mucositis due to its antiinflammatory and antibacterial properties. Lüer et al. [72] assessed the in vitro extent of bactericidal activity of curcumin on pharyngeal cells. Complete suppression of the release of TNF- $\alpha$, IL-6, IL-8, monocyte chemoattractant protein 1 , granulocyte macrophage-colony stimulating factor, and VEGF was observed. Repetitive exposure to curcumin resulted in repetitive suppression of cytokine/chemokine expression lasting from 4 to $6 \mathrm{~h}$. Therefore, the authors concluded that through reduction of oral microbial concentration and suppression of inflammation cascades, curcumin may play a role in oral mucositis.

Review of literature revealed four studies evaluating the role of curcumin in treatment and prevention of oral mucositis (Table 5).

Patil et al. [73] evaluated the efficacy and safety of curcumin mouthwash in comparison with chlorhexidine in the management of oral mucositis. Curcumin was found to be better than chlorhexidine mouthwash in terms of rapid wound healing and better patient compliance. No oral or systemic complications were reported in this study.

Saldanha and Almeida [74] compared turmeric and saline mouthwash on oral mucositis. There was a significant difference in the score of oral mucositis between pre-intervention on day 1 morning and postintervention score on day 5 evening in both turmeric and saline group but on comparison it was found that turmeric mouthwash was more effective than saline mouthwash in all the days except in day 3 where there was no significant difference found.

Elad et al. [75] undertook a pilot study to assess the tolerability of a curcumin mouthwash for the management of oral mucositis. They had originally designed a placebo-controlled study, but gastrointestinal adverse events (nausea and vomiting) affected the compliance of the first three participants who were receiving placebo. Due to ethical issues, the control group was discontinued and the authors reported their results as a case series. In this study, the authors suggested that curcumin mouthwash was safe and well-tolerated. 
Table 5: Review of literature showing four research papers assessing the efficacy of curcumin in oral mucositis patients

\begin{tabular}{|c|c|c|c|c|c|c|}
\hline S. No. & Author(s) & $\begin{array}{l}\text { Type of } \\
\text { evidence }\end{array}$ & $\mathbf{n}$ & Interventions & Outcomes & Results \\
\hline 1. & Patil et al. & RCT & $\begin{array}{l}20 \text { adult } \\
\text { cancer patients } \\
\text { undergoing } \\
\text { radiochemotherapy }\end{array}$ & $\begin{array}{l}\text { Study } \\
\text { subjects were } \\
\text { randomized to } \\
\text { receive either } \\
\text { chlorhexidine } \\
\text { mouthwash } \\
0.2 \% \text { or freshly } \\
\text { prepared } \\
\text { curcumin } \\
\text { mouthwash; } \\
\text { each to be used } \\
\text { thrice daily }\end{array}$ & $\begin{array}{l}\text { The WHO scale, the OMAS, } \\
\text { and NRS (NRS; patient } \\
\text { reporting scale of } 0-10 \text { ) } \\
\text { were used for assessment at } \\
\text { days } 0,10 \text {, and } 20 . \text { Adverse } \\
\text { events were tracked }\end{array}$ & $\begin{array}{l}\text { On the comparison between } \\
\text { the baseline and } 2^{\text {nd }} \text { follow-up } \\
\text { scores of the study and control } \\
\text { groups, NRS ( } \mathrm{p}<0.001) \text {, erythema } \\
\text { ( } \mathrm{p}=0.050) \text {, ulceration }(\mathrm{p}<0.001) \text {, } \\
\text { and WHO }(\mathrm{p}=0.003) \text { were found } \\
\text { to be statistically significant }\end{array}$ \\
\hline 2. & $\begin{array}{l}\text { Saldanha and } \\
\text { Almeida }\end{array}$ & $\begin{array}{l}\text { RCT with } \\
\text { pre- } \\
\text { post-test } \\
\text { time } \\
\text { series } \\
\text { design }\end{array}$ & $\begin{array}{l}40 \text { adult } \\
\text { cancer patients } \\
\text { undergoing } \\
\text { radiochemotherapy }\end{array}$ & $\begin{array}{l}\text { Group I receiving } \\
\text { turmeric } \\
\text { mouthwash } \\
\text { (mouthwash } \\
\text { solution } \\
\text { prepared by } \\
\text { mixing } 1.5 \mathrm{~g} \text { of } \\
\text { turmeric powder } \\
\text { with } 50 \text { ml of } \\
\text { water). Group II } \\
\text { received saline } \\
\text { mouth, } 3 \text { times / } \\
\text { day for } 5 \text { days }\end{array}$ & $\begin{array}{l}\text { Oral mucositis assessment } \\
\text { checklist and pain using pain } \\
\text { scale every morning } \\
\text { before the intervention } \\
\text { and evening after the } \\
\text { intervention }\end{array}$ & $\begin{array}{l}\text { The mean pre-test TIOM score } \\
\text { of Group I was } 25.35 \text { whereas } \\
\text { in post-test it is } 18.85 \text {. The } \\
\text { mean of pre-test TIOM score of } \\
\text { Group II was } 25.05 \text { whereas in } \\
\text { post-test it is } 20.15 \text {. The mean } \\
\text { post-interventional scores (day } 5 \\
\text { evening) in Groups I and II were } \\
\text { significantly lower than the mean } \\
\text { pre-interventional scores (day } 1 \\
\text { morning) In comparison, it was } \\
\text { found that turmeric mouthwash } \\
\text { was effective than a saline mouth } \\
\text { in all the days except in day } 3 \\
\text { where there was no significant } \\
\text { difference found }\end{array}$ \\
\hline 3. & Elad et al. & $\begin{array}{l}\text { Pilot } \\
\text { study }\end{array}$ & $\begin{array}{l}7 \text { pediatric and } \\
\text { young-adult } \\
\text { oncology patients } \\
\text { undergoing } \\
\text { doxorubicin- } \\
\text { containing } \\
\text { chemotherapy }\end{array}$ & $\begin{array}{l}10 \text { drops of } \\
\text { curcumall in a } \\
\text { half glass }(50 \mathrm{ml} \text { ) } \\
\text { of water twice } \\
\text { daily (equivalent } \\
\text { to } \\
330 \mathrm{mg} / \text { day), } \\
\text { in addition } \\
\text { to standard } \\
\text { preventive } \\
\text { oral care } \\
\text { (chlorhexidine } \\
0.2 \% \\
\text { mouthwash) } \\
\text { during treatment } \\
\text { with high dose } \\
\text { chemotherapy }\end{array}$ & $\begin{array}{l}\text { The primary outcome } \\
\text { measure was oral adverse } \\
\text { events related to curcumin } \\
\text { use, and secondary } \\
\text { outcome measures were } \\
\text { OMAS, WHO } \\
\text { mucositis scale, and VAS. OM } \\
\text { was assessed on days } 0,7 \text {, } \\
10,14 \text {, and } 21 \text { days }\end{array}$ & $\begin{array}{l}\text { No oral or systemic adverse } \\
\text { events were documented. In the } \\
\text { four patients who fulfilled the } \\
\text { compliance criteria, the WHO, } \\
\text { OMAS, and VAS scores were } \\
\text { lower than the severity of oral } \\
\text { mucositis previously reported } \\
\text { in the literature. } 4 \text { of the } 5 \\
\text { participants developed OM, but } \\
\text { the values were low, reflecting a } \\
\text { relatively mild case. Duration of } \\
\text { neutropenia ranged from } 3 \text { to } 8 \\
\text { days, with an average of } 4 \text {. Opioid } \\
\text { use ranged from } 0 \text { to } 4 \text { days with } \\
\text { an average of } 1.5 \text { days. Moreover, } \\
\text { finally, hospitalization ranged } \\
\text { for all subjects between } 0 \text { and } \\
12 \text { days with a median of } 7 \text {. No } \\
\text { parenteral nutrition was required }\end{array}$ \\
\hline 4. & Rao et al. & RCT & $\begin{array}{l}80 \text { head and neck } \\
\text { cancer patients } \\
\text { requiring } 70 \mathrm{~Gy} \\
\text { of radiation or } \\
\text { chemoradiotherapy }\end{array}$ & $\begin{array}{l}\text { Group I - } \\
\text { turmeric gargle } \\
\text { and Group } \\
\text { II - povidone- } \\
\text { iodine gargle } \\
\text { during chemo/ } \\
\text { radiotherapy } \\
\text { during the } \\
\text { period of } \\
\text { treatment }\end{array}$ & $\begin{array}{l}\text { Oral mucositis was assessed } \\
\text { using the RTOG grading } \\
\text { system before the start, } \\
\text { during, and at the end of the } \\
\text { treatment by an investigator } \\
\text { unaware of the treatment. } \\
\text { The primary endpoint of this } \\
\text { study was the incidence of } \\
\text { mucositis every week during } \\
\text { the 7-week period. The } \\
\text { secondary endpoint was the } \\
\text { effect of turmeric gargle on } \\
\text { the incidence of treatment } \\
\text { breaks, loss of scheduled } \\
\text { treatment days, and a } \\
\text { decrease in body weight at } \\
\text { the end of the treatment }\end{array}$ & $\begin{array}{l}\text { Compared with the cohorts using } \\
\text { povidone-iodine gargle, the group } \\
\text { using turmeric as a mouthwash } \\
\text { had delayed and reduced the } \\
\text { levels of radiation-induced oral } \\
\text { mucositis and was statistically } \\
\text { significant at all-time points } \\
(\mathrm{p}<0.001-\mathrm{p}<0.0001 \text { ). In addition, } \\
\text { the cohorts using turmeric had } \\
\text { decreased intolerable mucositis } \\
\text { (p<0.001) and lesser incidence of } \\
\text { the treatment breaks in the first } \\
\text { half of the treatment schedule } \\
\text { before } 4 \text { weeks ( }<<0.01 \text { ) and } \\
\text { reduced change in body weight } \\
\text { (p<0.001) }\end{array}$ \\
\hline
\end{tabular}


Rao et al. [76] in their single-blinded, randomized, controlled clinical trial compared turmeric gargle or povidone-iodine in head and neck cancer patients requiring 70 Gy of radiation or chemoradiotherapy (daily radiotherapy plus carboplatin once a week). They concluded that gargling with turmeric provided significant benefit by delaying and reducing the severity of mucositis.

\section{CONCLUSION}

Turmeric has been used in Ayurvedic medicine since ancient times, with various biological applications. Curcumin is a nontoxic, highly promising natural antioxidant compound having a wide spectrum of biological functions. It is expected that curcumin may find application as a novel drug in the near future to control various oral mucosal disorders. This paper reviewed the role of curcumin in tobaccoassociated and ulcerative conditions. Curcumin, therefore, fulfills two roles in the putative treatment of oral mucosal disorders, as an antiinflammatory agent, antioxidant, antimicrobial, and chemopreventive agent. It also provides the basis for a simple, safe, acceptable, and costeffective intervention for oral mucosal disorders.

\section{REFERENCES}

1. Priyadarsini KI. The chemistry of curcumin: From extraction to therapeutic agent. Molecules 2014;19:20091-112.

2. Chaturvedi TP. Uses of turmeric in dentistry: An update. Indian J Dent Res 2009;20:107-9.

3. Prasad S, Aggarwal BB, Benzie IF, Wachtel-Galor S, editors. Turmeric, the golden spice: From traditional medicine to modern medicine. In: Herbal Medicine: Biomolecular and Clinical Aspects. $2^{\text {nd }}$ ed., Ch. 3. Boca Raton (FL): CRC Press; 2011.

4. Kumar TP. Management of Horticultural Crops. Vol. 11., Part 1. New Delhi, India: New India Publishing; 2008.

5. Sharma DK, Maheshwari A, Gupta PM. Nutritional analysis of Curcuma longa L. In different cities of west Uttar Pradesh (INDIA). Int J Chem Pharm Sci 2013;4:7-14.

6. Jurenka JS. Anti-inflammatory properties of curcumin, a major constituent of Curcuma longa: A review of preclinical and clinical research. Altern Med Rev 2009;14:141-53

7. Chattopadhyay I, Biswas K, Bandyopadhyay U, Banerjee RK. Turmeric and curcumin: Biological actions and medicinal applications. Curr Sci 2004;87:44-50

8. Aggarwal BB, Sundaram C, Malani N, Ichikawa H. Curcumin: The Indian solid gold. Adv Exp Med Biol 2007;595:1-75.

9. Da'i M, Andi S, Edi M, Jenie UA, Masashi K. Apoptosis induction effect of curcumin and its analogs pentagamavunon- 0 and pentagamavunon-1 on cancer cell lines. Asian J Pharm Clin Res 2017;10:373-6.

10. Srinivasan M, Steffi PF. Curcumin, a potent anticarcinogenic polyphenol - A review. Asian J Pharm Clin Res 2014;7:1-8.

11. Devaraj SD, Neelakantan P. Curcumin - Pharmacological actions and its role in dentistry. Asian J Pharm Res Health Care 2013;6:19-22.

12. Mohan N, Rajashekhar RN, Kaiser J. Spicy anti-cancer spices: A review. Int J Pharm Pharm Sci 2015;7:1-6.

13. Pindborg JJ, Sirsat SM. Oral submucous fibrosis. Oral Surg Oral Med Oral Pathol 1966;22:764-79.

14. Brennan PA, Arakeri G. Oral submucous fibrosis-an increasing global healthcare problem. J Oral Pathol Med 2017;46:405.

15. Bar-Sela G, Epelbaum R, Schaffer M. Curcumin as an anti-cancer agent: Review of the gap between basic and clinical applications. Curr Med Chem 2010;17:190-7.

16. Bierhaus A, Zhang Y, Quehenberger P, Luther T, Haase M, Müller $\mathrm{M}$, et al. The dietary pigment curcumin reduces endothelial tissue factor gene expression by inhibiting binding of AP-1 to the DNA and activation of NF-kappa B. Thromb Haemost 1997;77:772-82.

17. Aggarwal BB, Prasad S, Reuter S, Kannappan R, Yadev VR, Park B, et al. Identification of novel anti-inflammatory agents from ayurvedic medicine for prevention of chronic diseases: "Reverse pharmacology" and "bedside to bench" approach. Curr Drug Targets 2011;12:1595-653.

18. Rao DS, Sekhara NC, Satyanarayana MN, Srinivasan M. Effect of curcumin on serum and liver cholesterol levels in the rat. J Nutr 1970;100:1307-15

19. Zhang SS, Gong ZJ, Li WH, Wang X, Ling TY. Antifibrotic effect of curcumin in TGF- $\beta$ 1-induced myofibroblasts from human oral mucosa. Asian Pac J Cancer Prev 2012;13:289-94

20. Kuttan R, Sudheeran PC, Josph CD. Turmeric and curcumin as topical agents in cancer therapy. Tumori 1987:73:29-31.

21. Li CJ, Zhang LJ, Dezube BJ, Crumpacker CS, Pardee AB. Three inhibitors of type 1 human immunodeficiency virus long terminal repeat-directed gene expression and virus replication. Proc Natl Acad Sci U S A 1993;90:1839-42.

22. Punithavathi D, Venkatesan N, Babu M. Curcumin inhibition of bleomycin-induced pulmonary fibrosis in rats. $\mathrm{Br} \mathrm{J}$ Pharmacol 2000;131:169-72.

23. Pipalia PR, Annigeri RG, Mehta R. Clinicobiochemical evaluation of turmeric with black pepper and Nigella sativa in management of oral submucous fibrosis-a double-blind, randomized preliminary study. Oral Surg Oral Med Oral Pathol Oral Radiol 2016;122:705-12.

24. Hazarey VK, Sakrikar AR, Ganvir SM. Efficacy of curcumin in the treatment for oral submucous fibrosis - A randomized clinical trial. J Oral Maxillofac Pathol 2015; 19:145-52

25. Srivastava A, Agarwal R, Chaturvedi TP, Chandra A, Singh OP. Clinical evaluation of the role of tulsi and turmeric in the management of oral submucous fibrosis: A pilot, prospective observational study. J Ayurveda Integr Med 2015;6:45-9.

26. Yadav M, Aravinda K, Saxena VS, Srinivas K, Ratnakar P, Gupta J, et al. Comparison of curcumin with intralesional steroid injections in oral submucous fibrosis - A randomized, open-label interventional study. J Oral Biol Craniofac Res 2014;4:169-73.

27. Das AD, Balan A, Sreelatha KT. Comparative study of the efficacy of curcumin and turmeric oil as chemopreventive agents in oral submucous fibrosis: A clinical and histopathological evaluation. J Indian Acad Oral Med Radiol 2010;22:88-92.

28. Rai B, Kaur J, Jacobs R, Singh J. Possible action mechanism for curcumin in pre-cancerous lesions based on serum and salivary markers of oxidative stress. J Oral Sci 2010;52:251-6.

29. Hastak K, Jakhi SD, More C, John A, Ghaisas SD, Bhide SV. Therapeutic response to turmeric oil and turmeric oleoresin in oral submucous fibrosis patient. Amala Res Bull 1998;18:23-8.

30. Warnakulasuriya S, Johnson NW, van der Waal I. Nomenclature and classification of potentially malignant disorders of the oral mucosa. J Oral Pathol Med 2007;36:575-80.

31. Greenberg MS, Glick M, Ship JD. Burket's Oral Medicine. $11^{\text {th }}$ ed. Hamilton (Canada): Elsevier; 2008. P. 85-8

32. Aggarwal BB, Kumar A, Bharti AC. Anticancer potential of curcumin: Preclinical and clinical studies. Anticancer Res 2003;23:363-98.

33. Piper JT, Singhal SS, Salameh MS, Torman RT, Awasthi YC, Awasthi S, et al. Mechanisms of anticarcinogenic properties of curcumin: The effect of curcumin on glutathione linked detoxification enzymes in rat liver. Int J Biochem Cell Biol 1998;30:445-56.

34. Susan M, Rao MN. Induction of glutathione S-transferase activity by curcumin in mice. Arzneimittelforschung 1992;42:962-4.

35. Jovanovic SV, Steenken S, Boone CW, Simic MG. H-Atom transfer is a preferred antioxidant mechanism of curcumin. J Am Chem Soc 1998; 121:9677-81.

36. Sharma RA, Ireson $\mathrm{CR}$, Verschoyle RD, Hill KA, Williams ML, Leuratti C, et al. Effects of dietary curcumin on glutathione S-transferase and malondialdehyde-DNA adducts in rat liver and colon mucosa: Relationship with drug levels. Clin Cancer Res 2001;7:1452-8.

37. Plummer SM, Holloway KA, Manson MM, Munks RJ, Kaptein A, Farrow $\mathrm{S}$, et al. Inhibition of cyclo-oxygenase 2 expression in colon cells by the chemopreventive agent curcumin involves inhibition of NF-kappaB activation via the NIK/IKK signalling complex. Oncogene 1999; 18:6013-20.

38. Plummer SM, Hill KA, Festing MF, Steward WP, Gescher AJ, Sharma RA, et al. Clinical development of leukocyte cyclooxygenase 2 activity as a systemic biomarker for cancer chemopreventive agents. Cancer Epidemiol Biomarkers Prev 2001;10:1295-9.

39. Chakravarti N, Kadara H, Yoon DJ, Shay JW, Myers JN, Lotan D, et al. Differential inhibition of protein translation machinery by curcumin in normal, immortalized, and malignant oral epithelial cells. Cancer Prev Res (Phila) 2010;3:331-8.

40. Cheng AL, Hsu CH, Lin JK, Hsu MM, Ho YF, Shen TS, et al. Phase I clinical trial of curcumin, a chemopreventive agent, in patients with high-risk or pre-malignant lesions. Anticancer Res 2001;21:2895-900.

41. Chiba I, Takeshima M, Abiko Y, Kobayashi H, Muthumala M, Sugiura C, et al. Curcumin is an effective chemopreventive substance for betel quid chewer's oral precancer in Sri Lanka. Cancer Prev Res 2012;5:4

42. Pindborg JJ, Mehta FS, Gupta PC, Daftary DK, Smith CJ. Reverse smoking in Andhra Pradesh, India: A study of palatal lesions among 10,169 villagers. Br J Cancer 1971;25:10-20

43. Vijayalaxmi N, Reddy RS, Ramesh T, Saimadhavi N, Reddy RL, Swapna LA. Efficacy of curcumin in treating palatal changes associated 
with reverse smoking. Arch Oral Res 2012;8:47-54.

44. Rajendran R, Sivapadasundaram B. Textbook of Oral Pathology. $7^{\text {th }}$ ed. New Delhi, India: Elsevier; 2012. p. 808-12.

45. Kumar V, Abbas A, Aster J. Robbins and Cotran Pathologic Basis of Disease. $8^{\text {th }}$ ed. Philadelphia, Pa, USA: Saunders; 2009.

46. Gorouhi F, Davari P, Fazel N. Cutaneous and mucosal lichen planus: A comprehensive review of clinical subtypes, risk factors, diagnosis, and prognosis. Sci World J 2014;2014:742826.

47. Andreasen JO. Oral lichen planus 1. A clinical evaluation of 115 cases. Oral Surg Oral Med Oral Pathol 1968;25:31-42.

48. Krupaa RJ, Sankari SL, Masthan KM, Rajesh E. Oral lichen planus: An overview. J Pharm Bioallied Sci 2015;7:S158-61.

49. Ismail SB, Kumar SK, Zain RB. Oral lichen planus and lichenoid reactions: Etiopathogenesis, diagnosis, management and malignant transformation. J Oral Sci 2007;49:89-106.

50. Chainani-Wu N, Silverman S Jr. Reingold A, Bostrom A, Mc Culloch C, Lozada-Nur F, et al. A randomized, placebo-controlled, double-blind clinical trial of curcuminoids in oral lichen planus. Phytomedicine 2007; 14:437-46

51. Chainani-Wu N, Madden E, Lozada-Nur F, Silverman S Jr. High-dose curcuminoids are efficacious in the reduction in symptoms and signs of oral lichen planus. J Am Acad Dermatol 2012;66:752-60.

52. Chainani-Wu N, Collins K, Silverman S Jr. Use of curcuminoids in a cohort of patients with oral lichen planus, an autoimmune disease. Phytomedicine 2012;19:418-23.

53. Singh V, Pal M, Gupta S, Tiwari SK, Malkunje L, Das S, et al. Turmeric - A new treatment option for lichen planus: A pilot study. Natl J Maxillofac Surg 2013;4:198-201.

54. Scully C, Porter S. Recurrent aphthous stomatitis: Current concepts of etiology, pathogenesis and management. J Oral Pathol Med 1989;18:21-7.

55. Preeti L, Magesh K, Rajkumar K, Karthik R. Recurrent aphthous stomatitis. J Oral Maxillofac Pathol 2011;15:252-6.

56. Stanley HR. Aphthous lesions. Oral Surg Oral Med Oral Pathol Oral Radiol Endod 1972;30:407-16.

57. Saja K, Babu MS, Karunagaran D, Sudhakaran PR. Anti-inflammatory effect of curcumin involves downregulation of MMP-9 in blood mononuclear cells. Int Immunopharm 2007;7:1659-67.

58. Aggarwal BB, Harikumar KB. Potential therapeutic effects of curcumin, the anti-inflammatory agent, against neurodegenerative, cardiovascular, pulmonary, metabolic, autoimmune and neoplastic diseases. Int J Biochem Cell Biol 2009;41:40-59.

59. Mukhopadhyay A, Basu N, Ghatak N, Gujral PK. Anti-inflammatory and irritant activities of curcumin analogues in rats. Agents Actions 1982;12:508-15.

60. Swarnakar S, Ganguly K, Kundu P, Banerjee A, Maity P, Sharma AV, et al. Curcumin regulates expression and activity of matrix metalloproteinases 9 and 2 during prevention and healing of indomethacin-induced gastric ulcer. J Biol Chem 2005;280:9409-15.

61. Panchatcharam M, Miriyala S, Gayathri VS, Suguna L. Curcumin improves wound healing by modulating collagen and decreasing reactive oxygen species. Mol Cell Biochem 2006;290:87-96.

62. Zaher AR, Elsabaa HM, Elkhier MT, Elhindawy MM. Impact of curcumin on tongue ulcer healing in albino rats. Mansoura J Dent 2014; $1: 85-9$

63. Thorat Y, Sarvagod A, Kulkarni S, Hosmani A. Treatment of mouth ulcer by curcumin loaded thermoreversible mucoadhesive gel: A technical note. Int J Pharm Pharm Sci 2015;7:399-402.

64. Deshmukh RA, Bagewadi AS. Comparison of effectiveness of curcumin with triamcinolone acetonide in the gel form in treatment of minor recurrent aphthous stomatitis: A randomized clinical trial. Int J Pharm Investig 2014;4:138-41.

65. Halim DS, Khalik NIBA, Taib H, Pohchi A, Hassan A, Alam MK. Novel material in the treatment of minor oral recurrent aphthous stomatitis. Int Med J 2013;20:392-4

66. Manifar S, Obwaller A, Gharehgozloo A, Kordi HR, Akhondzadeh S. Curcumin gel in treatment of minor aphthous ulcer: A randomized, placebo-controlled trial. J Med Plants 2012;11:41.

67. Antharjanam SD, Balan A. Curcumin as a treatment modality in recurrent aphthous stomatitis. KSDJ 2009;32:206-8

68. Al-Saffar MT. The therapeutic effect of viscous solution of curcumine in the treatment of recurrent aphthous stomatitis (RAS). Al-Rafidain Dent J 2006;6:48-52.

69. Lalla RV, Sonis ST, Peterson DE. Management of oral mucositis in patients who have cancer. Dent Clin North Am 2008;52:61-77, 8 .

70. Naidu MU, Ramana GV, Rani PU, Mohan IK, Suman A, Roy P, et al. Chemotherapy-induced and/or radiation therapy-induced oral mucositis - Complicating the treatment of cancer. Neoplasia 2004;6:423-31.

71. Georgiou M, Patapatiou G, Domoxoudis S, Pistevou-Gompaki K, Papanikolaou A. Oral mucositis: Understanding the pathology and management. Hippokratia 2012;16:215-6.

72. Lüer S, Troller R, Aebi C. Antibacterial and antiinflammatory kinetics of curcumin as a potential antimucositis agent in cancer patients. Nutr Cancer 2012;64:975-81.

73. Patil K, Guledgud MV, Kulkarni PK, Keshari D, Tayal S. Use of curcumin mouthrinse in radio-chemotherapy induced oral mucositis patients: A Pilot study. J Clin Diagn Res 2015;9:ZC59-62.

74. Saldanha SP, Almeida VD. A comparative study to assess the effectiveness of turmeric mouth wash versus saline mouth wash on treatment induced oral mucositis (Tiom) in a selected hospital at Mangalore. J Clin Res Bioeth 2014;5:200.

75. Elad S, Meidan I, Sellam G, Simaan S, Zeevi I, Waldman E, et al. Topical curcumin for the prevention of oral mucositis in pediatric patients: Case series. Altern Ther Health Med 2013;19:21-4

76. Rao S, Dinkar C, Vaishnav LK, Rao P, Rai MP, Fayad R, et al. The Indian spice turmeric delays and mitigates radiation-induced oral mucositis in patients undergoing treatment for head and neck cancer: An investigational study. Integr Cancer Ther 2014;13:201-10. 